\title{
Efektifitas Pembelajaran Daring Mahasiswa Pendidikan Matematika ditengah Pandemi Covid-19
}

\author{
Syarifuddin* \\ STKIP Bima, Bima, Indonesia \\ Hasan Basri \\ Universitas Madura, Madura, Indonesia \\ M. Ilham \\ Mahasiswa Pendidikan Matematika, STKIP Bima, Bima, Indonesia \\ Ade Fitri Fauziah \\ Mahasiswa Pendidikan Matematika, STKIP Bima, Bima, Indonesia \\ *Coresponding Author: syarifuddin.stkipbima@gmail.com \\ Dikirim: 18-05-2021 ; Direvisi: 18-05-2021 ; Diterima: 19-05-2021
}

\begin{abstract}
Abstrak: Penelitian bertujuan mengetahui keefektifan pembelajaran daring mahasiswa program studi pendidikan matematika ditengah pandemi covid-19. Penelitian ini menggunakan pendekatan deskriptif eksploratif dalam cakupan penelitian kualitatif. Subjek penelitian adalah mahasiswa aktif program studi pendidikan matematika STKIP Bima dan Universitas Madura semester ganjil tahun akademik 2020/2021. Data penelitian diperoleh dengan menggunakan angket dalam bentuk google form yang di isi oleh mahasiswa diakhir semester ganjil melalui smartphone atau leptop. Selanjutnya mahasiswa dilakukan wawancara untuk memperoleh informasi pendukung dari angket. Instrumen tersebut berbentuk skala pilihan dan jawaban singkat. Data yang diperoleh dianalisis secara deskriptif yang diawali dengan pengelompokkan berdasarkan kategori tanggapan, kemudian mendeskripsikan tanggapan yang berbeda dari mahasiswa. Penelitian ini menemukan kendala dalam proses pembelajaran daring yaitu masalah ekonomi mahasiswa yang dapat berpengaruh kepada kepemilikan handphone sesebagai penunjang utama pembelajaran daring, terkendala pada paket internet atau jaringan wifi, serta jaringan yang kurang baik dilingkungan mahasiswa. Penelitian ini juga mengungkapkan kesulitan mahasiswa dalam pembelajaran daring pada mata kuliah yang bersifat hitungan dibandingkan dengan mata kuliah yang hanya bersifat teori.
\end{abstract}

Kata Kunci: Pembelajaran Daring, Pendidikan Matematika, Pandemi Covid-19

Abstract: The study aims to determine the effectiveness of online learning for students of mathematics education study programs in the midst of the Covid-19 pandemic. This study uses a descriptive exploratory approach within the scope of qualitative research. The research subjects were active students of the STKIP Bima and Madura University mathematics education study program in the odd semester of the 2020/2021 academic year. The research data was obtained by using a questionnaire in the form of goggle form which was filled in by students at the end of the odd semester via a smart phone or laptop. Then the students were interviewed to obtain supporting information from the questionnaire. The instrument is in the form of a scale of choices and short answers. The data obtained were analyzed descriptively, starting with grouping by category of responses, then describing the different responses from students. This study found obstacles in the online learning process, namely student economic problems that could affect the ownership of cell phones as the main support for online learning, constraints on internet packages or WiFi networks, as well as poor networks in the student environment. This study also revealed students' difficulties in online learning in subjects that were computational in nature compared to courses that were only theoretical.

Keywords: Online Learning, Mathematics Education, Covid-19 Pandemic

@ 2021 JagoMipa (https://bimaberilmu.com/jurnal/index.php/jagomipa) 


\section{PENDAHULUAN}

Pembelajaran pada prinsipnya adalah proses yang terjadi didalam kelas yang berlangsung antara guru dan siswa dengan memanfaatkan sarana pendukung yang ada dilingkungan maupun sekolah. Pembelajaran seperti ini disebut dengan pembelajaran langsung atau istilah terkini disebut dengan pembelajaran luring (luar jaringan). Pembelajaran luring berlangsung dalam satu ruang dan waktu antara guru dan siswa.

Pembelajaran luring tidak asing bagi semua kalangan, baik yang sudah mengenal teknologi dengan baik maupun masyarakat yang buta akan teknologi. Demikian juga untuk masyarakat yang hidup di perkotaan maupun masyarakat yang hidup di daerah terpencil. Seiring berkembangnya ilmu pengetahuan dan teknologi, proses pembelajaran pada masa sekarang ini tidak hanya berlangsung dalam ruangan secara luring, akan tetapi dapat berlangsung walaupun tidak berada pada ruangan dan waktu yang bersamaan. Pembelajaran seperti ini biasa dikenal dengan istilah pembelajaran daring (dalam jaringan) yang merupakan kebalikan dari pembelajaran luring. Sebelum ada istilah pembeajaran daring, dulu dikenal ada pembelajaran berbantuan internet (Syarifuddin \& Mikrayanti, 2015), yaitu pembelajaran luring dengan memanfaatkan fasilitas internet didalam kelas.

Sebelum wabah pandemi covid-19, pembelajaran daring hanya dikenal pada kalangan tertentu saja, misalnya mahasiswa yang kuliah di Universitas Terbuka (UT), siswa ataupun mahasiswa yang sudah mengenal teknologi dengan baik, ataupun siswa dan mahasiswa yang ada di kota-kota besar. Sementara itu, bagi siswa ataupun mahasiswa dengan teknologi masih rendah atau yang berada di daerah terpencil, sangat asing dengan istilah atau pelaksanaan pembelajaran daring. Tetapi pembelajaran luring pada

Sementara itu, diakhir tahun 2019 muncul wabah covid-19 yang menyebabkan pergerakan dan perkumpulan orang dibatasi, termasuk larangan untuk pembelajaran luring untuk menekan penyebaran wabah tersebut. Larangan tersebut tertuang dalam Press Release Presiden RI tanggal 15 Maret 2020 tentang Sikap Pemerintah terhadap pandemi COVID-19 (Presiden RI, 2020), Surat Edaran Menteri Pendidikan dan Kebudayaan RI No. 3 Tahun 2020 tanggal 9 Maret 2020 tentang pencegahan COVID-19 pada Satuan Pendidikan (Kemdikbud, 2020), dan Surat Edaran plt. Direktur Jenderal Pendidikan Tinggi No. 302/E.E2/KR/2020 tanggal 31 Maret 2020 tantang Masa Belajar Penyeelenggaraan Program Pendidikan (Dirjendikti, 2020), serta beberapa himbauan yang dikeluarkan oleh pemerintah daerah.

Larangan tersebut mengharuskan semua jenjang pendidikan melaksanakan pembelajaran secara daring hingga sampai pendidikan tinggi, termasuk didalamnya adalah Sekolah Tinggi Keguruan dan Ilmu Pendidikan (STKIP) Bima dan Universitas Madura. Di program studi pendidikan matematika melaksanakan proses pembelajaran melalui beberapa aplikasi pendukung, misalnya menggunakan zoom, whatssap, google meet, dan beberapa aplikasi lainnya.

Pembelajaran melalui aplikasi daring sudah dilakukan kajian dan penelitian sebelumnya. Pembelajaran daring tidak efektik ketika tidak didukung oleh sarana dan prasarana teknologi yang memadai (Ameli dkk, 2020), sehingga perlu ada persiapan dan pembekalan tentang teknologi yang digunakan kepada dosen maupun mahasiswa. Kemudian hasil penelitian lain mengungkapkan bahwa pembelajaran

@ 2021 JagoMipa (https://bimaberilmu.com/jurnal/index.php/jagomipa) 
daring sudah efektif dilaksanakan, namun perlu memperbaiki struktur materi (Hapsari \& Fitria, 2020).

Penelitian ini mengkaji hal yang berbeda yaitu ingin mengetahui efektifitas pembelajaran daring pada mahasiswa program studi pendidikan matematika. Hal ini didasarkan pada informasi awal dari beberapa mahasiswa yang merasakan kesulitan saat melaksanakan pembelajaran di mata kuliah yang berbasis hitungan. Penelitian ini juga ingin mengetahui kesiapan sarana pendukung dalam proses pembelajaran daring, khususnya di sekitar lingkungan kampus maupun lingkungan tempat tinggal mahasiswa program studi pendidikan matematika STKIP Bima dan Universitas Madura.

\section{METODE PENELITIAN}

Penelitian ini merupakan penelitian kualitatif dengan pendekatan deskriptif yaitu menguraikan data hasil penelitian dengan cara memaknai dan menjelaskan temuan-temuan hasil penelitian.

\section{Subjek Penelitian}

Penelitian dilakukan pada mahasiswa program studi pendidikan matematika STKIP Bima dan Universitas Madura yang aktif kuliah pada semester ganjil tahun akademik 2020/2021. Subjek yang terlibat dalam penelitian adalah mahasiswa yang berpartisipasi dan memberikan respon terhadap angket yang dibagikan secara online melalui grup whatsshap. Sehingga subjek dalam penelitian ini sebanyak 45 orang yang memberikan respon.

\section{Pengumpulan Data}

Data penelitian dikumpulkan dengan menggunakan angket yang berisi 2 (dua) masalah pokok yaitu tentang sarana dan prasarana pendukung pembelajaran dan proses pembelajaran daring dengan jumlah pertanyaan/pernyataan sebanyak 11 butir. Angket tersebut diintegasikan kedalam google form yang dapat di isi secara online. Link anket dalam bentuk google form kemudian dibagikan kedalam grup whatsssap dan meminta kesediaan mahasiswa untuk mengisinya.

\section{Analisis Data}

Data yang diperoleh dalam penelitian ini berupa data kategori dan jawaban singkat dari mahasiswa yang merespon angket. Prosedur analisis data yaitu diawali dengan mengkategorikan jenis respon yang diberikan oleh mahasiswa dalam angket. Dari beberapa kategori tersebut kemudian dideskripsikan dengan cara mengkomparasikannya dari jenis kategori yang berbeda. Kemudian dari jawaban singkat mahasiswa menjadi penguat dan sebagai bukti dalam mendeskripsikan data.

\section{HASIL PENELITIAN DAN PEMBAHASAN}

Data dari hasil penelitian ini berupa data kategori dan uraian jawaban singkat dari mahasiswa. Data kategori terdiri dari 3 (tiga) pilihan untuk setiap butir dan memiliki kategori yang berbeda untuk masing-masing butir, sehingga dapat dideskripsikan masing-masing pertanyaan (pernyataan). Paparan data ini akan dibagi 
dalam 2 (dua) kelompok data yaitu data penunjang perkuliahan daring dan data proses pembelajaran daring sebagai berikut.

\section{Penunjang Pembelajaran Daring}

Data yang diperoleh dalam menggali sarana penunjang pembelajarang daring berupa fasilitas utama yang dimiliki oleh mahasiswa. Tidak semua mahasiswa memiliki smart phone yang dapat digunakan dalam proses pembelajaran daring, hal ini terlihat dari jawaban mahasiswa saat memberikan respon terhadap pertanyaa apakah memiliki handphone, seperti terlihat pada pada Gambar 1.

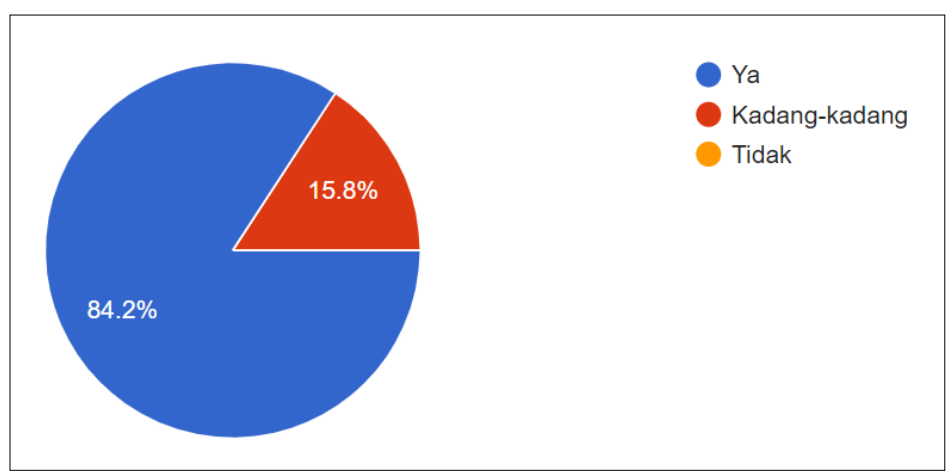

Gambar 1. Porsentase siswa yang memiliki dan tidak memiliki handphone

Dari Gambar 1 terlihat 84,2\% mahasiswa memiliki handphone, sementara terdapat $15,8 \%$ mahasiswa kadang-kadang memiliki handphone. Ini berarti, terdapat mahasiswa yang tidak dapat mengikuti proses pembelajaran dengan baik karena terkendala dengan fasilitas handphone. Saat di konfirmasi kenapa mereka memberika respon kadang-kadang memiliki, mahasiswa memberikan alasan handphone rusak dan belum ada dana untuk memperbaiki atau membeli pengganti yang baru.

Beberapa kendala lain dari sarana dan prasarana penunjang pembelajaran daring adalah masalah kuota dan jaringan internet. Untuk masalah paket data, masih banyak mahasiswa yang tidak mendapatkan paket data dari pemerintah. Hanya 57,9\% mahasiswa mendapatkan paket data dari pemerintah, sementara terdapat 42,1\% mahasiswa tidak mendapatkan paket data, hal ini terlihat pada Gambar 2 .

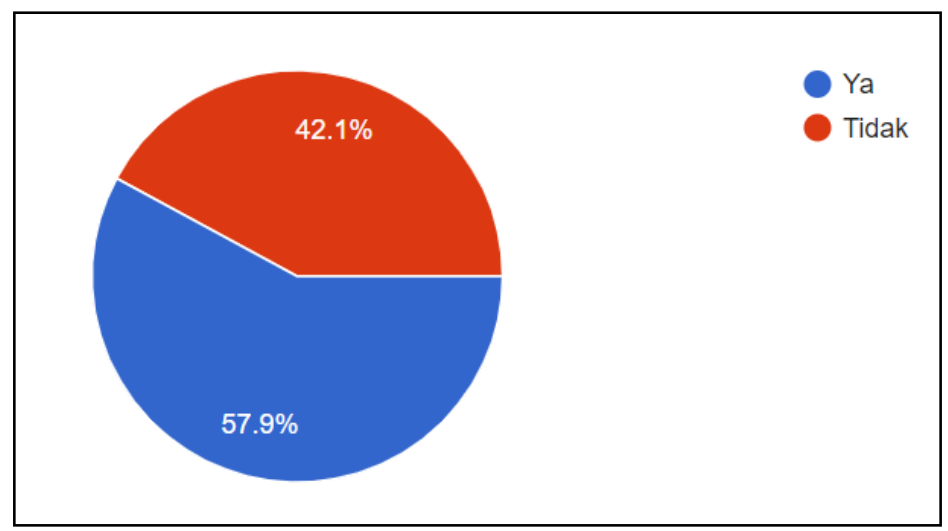

Gambar 2. Porsentase mahasiswa yang mendapatkan dan tidak mendapatkan paket data dari pemerintah 
Untuk masalah jaringan internet, rata-rata mahasiswa memberikan respon kurang lancar. Terdapat 63,2 \% mahasiswa memberikan respon bahwa jaringan dilingkungan mereka kurang lancar, sehingga pembelajaran secara daring tidak berjalan secara maksimal. Hal ini terlihat pada gambar 3 .

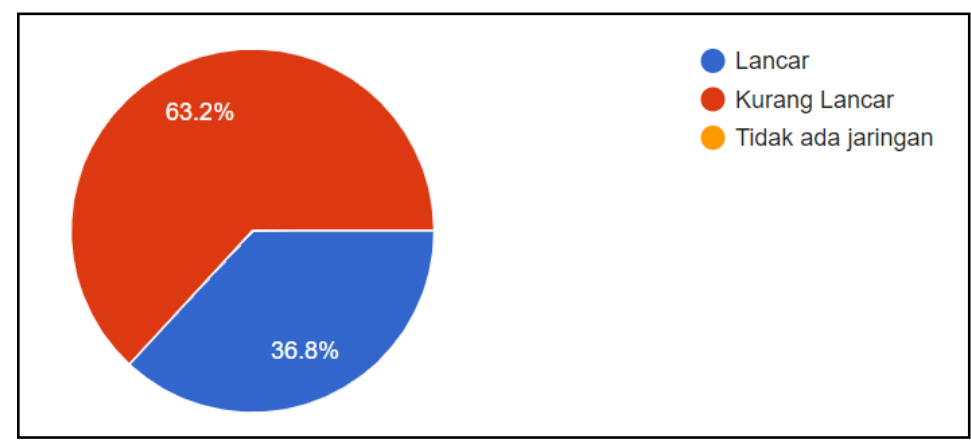

Gambar 3. Porsentase keadaan jaringan internet dilingkungan mahasiswa

Beberapa kendala terkait fasilitas penunjang pembelajaran daring tersebut diperkuat oleh pernyataan mahasiswa dari respon jawaban singkat terkait fasilitas pembelajaran daring, seperti pada Gambar 4.

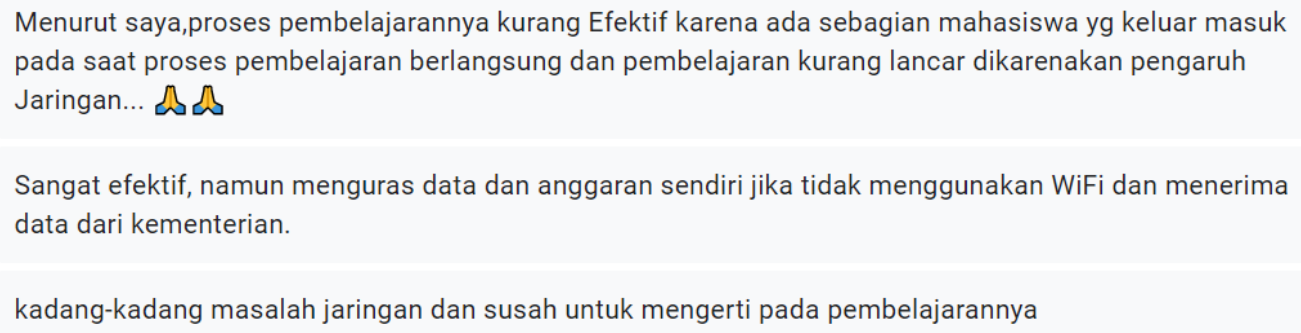

Gambar 4. Pernyataan mahasiswa terkait dengan fasilitas pembelajaran daring.

Dari sisi fasilitas penunjang pembelajaran daring, banyak sekali kendala yang dihadapi mahasiswa maupun dosen dalam pelaksanaannya. Pembelajaran daring di era covid-19 terkendala pada sarana dan prasarana yang terbatas dan kurang memadai, serta kesediaan dan kesiapan dosen maupun guru yang masih kurang terhadap media pembelajaran (Fauziyah, 2020; Sadikin, \& Hamidah, 2020), dan kendala pada keadaan ekonomi mahasiswa atau peserta didik (Abidin, Hudaya, \& Anjani, 2020).

\section{Proses Pembelajaran Daring}

Data proses pembelajaran daring di program studi pendidikan matematika di awali dengan pertanyaan masalah semangat pembelajaran yang diikuti oleh mahasiswa. Mahasiswa menunjukan kurang semangat dalam mengikuti pembelajaran. Hal ini ditunjukan dari hasil respon yang diberikan seperti pada Gambar 5. 


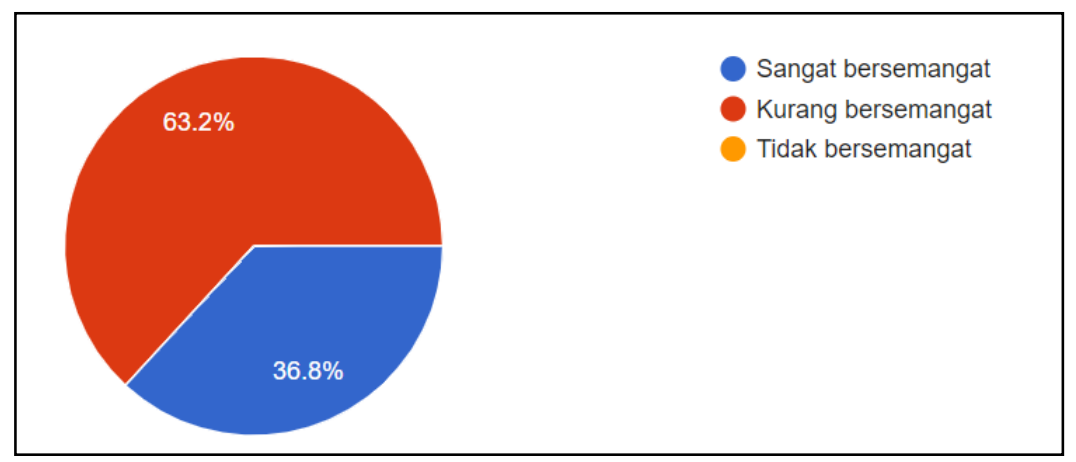

Gambar 5. Porsentase semangat mahasiswa dalam mengikuti perkuliahan daring

Dari Gambar 5 menunjukan mahasiswa yang kurang bersemangat mengikuti pembelajaran daring sebesar $63,2 \%$. Ini menunjukan lebih dari setengah mahasiswa kurang bersemangat. Beberapa kendala yang dihadapi mahasiswa tentu memicu terjadinya kekurangan semangat dalam melaksanakan pembelajaran daring.

Kemudian dari sisi pemahaman saat mengikuti pembelajaran daring, mahasiswa juga menunjukan tingkat pemahaman yang sangat kurang, hal ini terlihat pada Gambar 6.

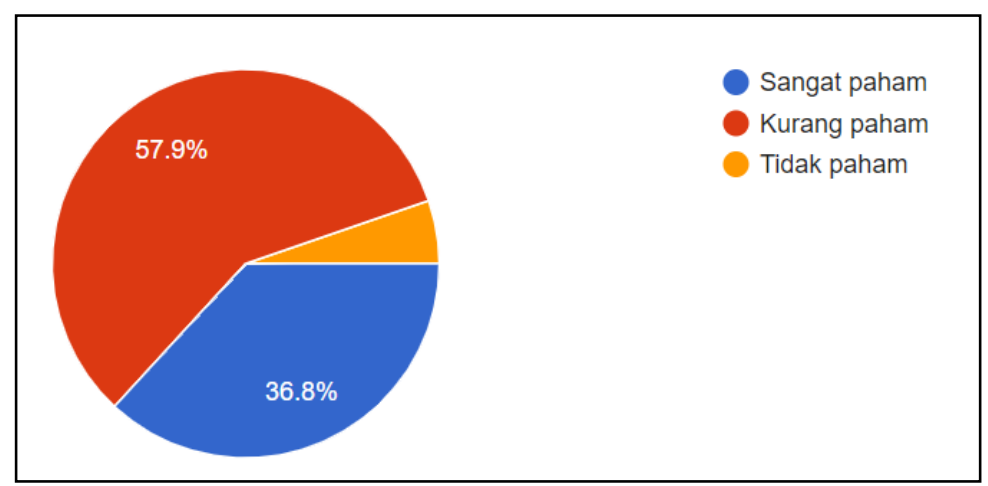

Gambar 6. Porsentase pemahaman mahasiswa dalam pembelajaran daring

Dari Gambar 6 terlihat dari respon dari mahasiswa yang menunjukan 5,3\% mahasiswa tidak paham, 57,9\% kurang paham, dan hanya 36,8\% mahasiswa yang sangat paham. Ini menunjukan bahwa tidak banyak mahasiswa yang dapat memahami materi perkuliahan dalam pembelajaran daring. Hal ini disebabkan juga oleh faktor fasilitas penunjang, sehingga menimbulkan ketidaklancaran pembelajaran. Ketidaklancaran proses penmbelajaran daring ini dapat terlihat pada Gambar 7.

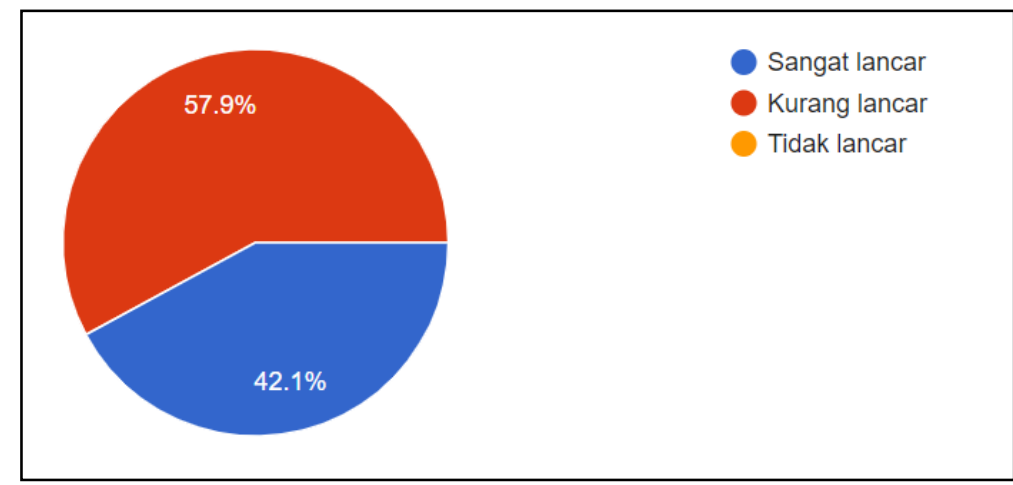

Gambar 7. Porsentase respon mahasiswa terhadap kelancaran pembelajaran daring 
Terdapat 57,9\% mahasiswa memberikan respon bahwa pembelajaran daring kurang lancar, dan 42,1\% merespon dengan sangat lancar. Jadi tidak semua mahasiswa dapat memperoleh materi atau pemahaman yang baik saat dosen menyampaikan perkuliahan atau pembelajaran secara daring.

Sebagai penguat data tersebut di atas, pad Gambar 8 disajikan respon mahasiswa dalam bentuk jawaban singkat terhadap pembelajaran daring.

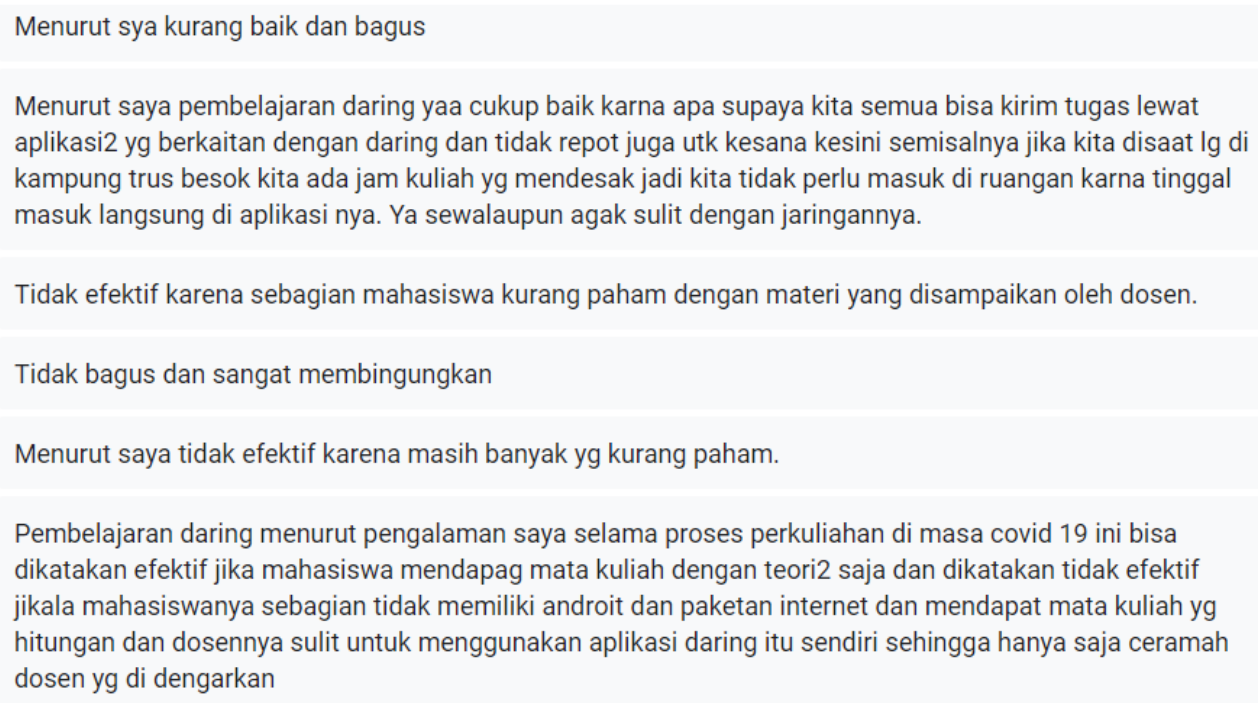

Gambar 8. Pernyataan mahasiswa terkait proses pembelajaran daring

Secara umum, mahasiswa memberikan tanggapan bahwa pembelajaran daring di program studi pendidikan matematika masih kurang efektik. Terutama dari sisi kesiapan materi yang disampaikan oleh dosen. Apalagi pada mata kuliah matematika murni atau yang berbentuk hitungan. Secara kuantitas, keinginan mahasiswa untuk memilih pelaksanaan perkuliahan secara daring tidak begitu besar, hal ini ditunjukan juga dari hasil penelitian yang mengatakan bahwa dari 1000 orang mahasiswa, hanya $1 \%$ yang menginginkan perkuliahan daring, sedangkan $79 \%$ menginginkan perkuliahan secara luring (Dewantara \& Nurgiansah, 2021).

Upaya perbaikan dalam pelaksanaan pembelajaran daring agar lebih efektif adalah lebih utamanya pada persiapan dosen atau guru. Pembelajaran daring menuntut dosen atau guru lebih siap dalam mendesain materi maupun bahan ajar yang disampaikan (Fauziyah, 2020; Kurniasari, Pribowo, \& Putra, 2020). Disamping itu, pembelajaran daring dapat dilaksanakan secara bergantian dengan pembelajaran luring (Widiyono, 2020).

\section{KESIMPULAN}

Penelitian tentang efektifitas pembelajaran daring di program studi pendidikan matematika dapat disimpulkan dari 2 (dua) aspek penting yaitu sarana penunjang pembelajaran daring dan proses pelaksanaan pembelajaran daring. Dari sarana penunjang, mahasiswa menghadapi beberapa kendala diantaranya adalah masalah ekonomi yang tidak mendukung untuk memiliki handphone dan paket data sebagai pendukung utama dalam pembelajaran daring. Kemudian faktor penting lainnya adalah kendala jaringan internet yang tidak begitu bagus dilingkungan sekitar tempat 
tinggal mahasiswa. Kemudian dari segi proses pelaksanaan pembelajaran daring dapat ditarik kesimpulan bahwa pembelajaran daring berjalan tidak begitu efektif dan pemahaman mahasiswa masih sangat kurang. Hal ini terjadi karena desain materi maupun kesiapan dosen dalam pelaksanaan pembelajaran daring masing kurang, teruatama pada mata kuliah yang sifatnya hitungan atau mata kuliah matematika murni.

Untuk mengantisipasi masalah ini, perguruan tinggi perlu memberikan perhatian khusus terhadap mahasiswa dan dosen untuk membatu memberikan fasilitas penunjang dalam pelaksanaan pembelajaran daring. Kemudian dosen perlu diberikan pembekalan yang baik dalam menggunakan fasilitas maupun aplikasi pembelajaran daring dan menyusun persiapan materi dengan sebaik mungkin.

\section{DAFTAR PUSTAKA}

Abidin, Z., Hudaya, A., \& Anjani, D. (2020). Efektivitas Pembelajaran Jarak Jauh pada Masa Pandemi Covid-19. Research and Development Journal of Education, 1(1), 131-146.

Ameli, A., Hasanah, U., Rahman, H., \& Putra, A. M. (2020). Analisis keefektifan pembelajaran online di masa pandemi COVID-9. Mahaguru: Jurnal Pendidikan Guru Sekolah Dasar, 2(1), 28-37.

Dewantara, J. A., \& Nurgiansah, T. H. (2021). Efektivitas Pembelajaran Daring di Masa Pandemi COVID 19 Bagi Mahasiswa Universitas PGRI Yogyakarta. Jurnal Basicedu, 5(1), 367-375.

Dirjendikti (2020). Surat Edaran plt. Direktur Jenderal Pendidikan Tinggi No. 302/E.E2/KR/2020 tanggal 31 Maret 2020 tantang Masa Belajar Penyeelenggaraan Program Pendidikan. Jakarta.

Fauziyah, N. (2020). Dampak Covid-19 Terhadap Efektivitas Pembelajaran Daring Pendidikan Islam. Al-Mau'izhoh, 2(2).

Hapsari, T. P. R. N., \& Fitria, A. S. (2020). Efektivitas Pembelajaran Daring Mata Kuliah Evaluasi Pengajaran Bahasa dan Sastra Indonesia Masa Pandemi Covid19. Jurnal Ilmiah SEMANTIKA, 2(01).

Kemdikbud (2020). Surat Edaran Menteri Pendidikan dan Kebudayaan RI No. 3 Tahun 2020 tanggal 9 Maret 2020 tentang pencegahan COVID-19 pada Satuan Pendidikan. Jakarta.

Kurniasari, A., Pribowo, F. S. P., \& Putra, D. A. (2020). Analisis Efektivitas Pelaksanaan Belajar Dari Rumah (BDR) Selama Pandemi Covid-19. Jurnal Review Pendidikan Dasar: Jurnal Kajian Pendidikan Dan Hasil Penelitian, 6(3), 246-253.

Presiden RI (2020). Press Release Presiden RI tanggal 15 Maret 2020 tentang Sikap Pemerintah Terhadap Pandemi COVID-19. Jakarta.

Sadikin, A., \& Hamidah, A. (2020). Pembelajaran Daring di Tengah Wabah Covid19:(Online Learning in the Middle of the Covid-19 Pandemic). Biodik, 6(2), 214-224.

Syarifuddin \& Mikrayanti (2015). Meningkatkan Kemandirian dan Motivasi Belajar Mahasiswa Melalui Metode Pemberian Tugas Berbantuan Internet Mata kuliah Strategi Belajar Mengajar. Jurnal Pendidikan MIPA, 5 (2), 137-148.

Widiyono, A. (2020). Efektifitas perkuliahan daring (online) pada mahasiswa PGSD di saat pandemi covid 19. Jurnal Pendidikan, 8(2), 169-177. 